\title{
Growing Metalwork Craft Businesses through the Lens of Entrepreneurship Education
}

\author{
Arikpo Sampson Venatius ${ }^{1^{*}}$, Aede Hatib Musta'amal ${ }^{2}$, Ogumbe Boniface Ekwok ${ }^{3}$, Otu Aniema Edet ${ }^{4}$ \\ ${ }_{1,2}$ Department of Technical and Engineering Education, Universiti Technologi Malaysia (UTM), Johor, 81310, Malaysia. \\ ${ }^{3}$ Department of Technical Education, Cross River University of Technology, 1123 Calabar, Nigeria. \\ ${ }^{4}$ Department of Business Education, University of Uyo (Uniyo), Uyo, 1017, Nigeria \\ * Corresponding author: svarikpo@graduate.utm.my
}

Submission: 30 July $2020 \quad$ Revised: 24 September $2020 \quad$ Published: 02 December 2020

\begin{abstract}
The problems of unemployment and poverty among technical education graduates require students to develop employability skills. One way of solving these problems is through the effective teaching of entrepreneurship education, especially at technical-based higher institutions. The research adopted the narrative review approach that seeks to give an understanding of current knowledge on the rationale of metalwork craft, the concept of entrepreneurship education, school-based enterprise and their usefulness for graduates' employment and productivity in Nigerian. The review showed that entrepreneurship education in the Nigerian higher education institutions seems to be more about creating entrepreneurship awareness, as against the practical approach, which is a means for developing entrepreneurship skills. Some challenges were highlighted that impede the successful implementation of entrepreneurship studies in Nigeria and recommendations made for practical realization of entrepreneurship education in institutions of higher learning.
\end{abstract}

Keywords: Metal Crafts Business, School-based Enterprise, Entrepreneurship Education

\section{INTRODUCTION}

Entrepreneurship Education (EE) plays a crucial role in the economy of any nation (Tende, 2014; Kumar, 2011; Agbonifor, Ehiametor, Inegbenebor \& Iyaji, 1999). Nigeria as a developing nation needs to give attention to an education by which students can harness their skills to create a job or earn a living through their ingenuity of local technology. EE is aimed at developing students mind for the pursuant of entrepreneurial life skills and attributes (Osalor, 2013) and to instil into the students' the knowledge or experiences that will enable them to venture into businesses (Wikipedia, 2014; Azi, 2013). This kind of education gained support by the Federal Government of Nigeria when it was made clear that Nigeria needs functional and practicable training, which allows for the acquisition skills and individuals' contribution to the development of society. The World Bank report of 2014 shows that entrepreneurship training is a catalyst for innovation and job creation initiatives among university graduates in Sub-Saharan Africa, where it has been observed that graduate unemployment rates are high. Also, the World Economic Forum (WEF) recognized the teaching of entrepreneurship as a key variable to combating unemployment. However, promoting an entrepreneurship culture entails teaching a set of cognitive and non-cognitive skills that focuses on inculcating in an individual the capabilities, skills and attributes to be self-reliant upon graduation (Olajide, 2019; Asotibe, 2015; Olorunmolu \& Agbede, 2012; Kuratko \& Hodgetts, 2001). For industrial technology students, learning entrepreneurship should include skills-building in negotiation, leadership, new product development, creative thinking and exposure to technological innovations.

According to the Federal Government of Nigeria (FGN) (2013) vocational entrepreneurial training promise to educated students to transform knowledge through technological processes into wealth for self-reliant and providers employment. Consequently, the Federal Government had made several policies and reeled out interventions programmes aimed at stimulating entrepreneur development. The National Directorate of Employment (NDE) established the entrepreneurship programme and in 2006, the Federal Government recognized its importance and mandated all tertiary institutions in Nigeria to include to their graduation requirement the study of entrepreneurship education has been made a compulsory course of study for students in Nigerians' tertiary institutions, effective from the 2007/2008 academic year. According to (Olajide, 2019; Alaki, 2015; Tende, 2014; Araba, 2012) it is hoped that the outcome of entrepreneurship study will not only take many Nigerians out from the doldrums of poverty, social vices but also will enable the recipient to acquire skills for innovation, creativity and ability to turn such attribute into money making opportunities.

Entrepreneurship education encompasses small and medium enterprises (SMEs), which serves as the generator of employment and increased productivity through innovation, the facilitation of transfer or adaptation of technology (Ikotun, Oladimeji, Oyende \& Olayemi, 2014; Sagagi, 2006; Osuagwu, 2001). Organization for Economic and Co-operative Development (OECD), Globally, SMEs accounts 95\% of all firms, Gross Domestic Product (GDP) $50 \%$ and about 60\% - 70\% of employment rate in OECD countries. SMEs are indeed the backbone of the British 
economy, contributing for about more than half of the trade turnover. Today, SMEs accounts for 99\% of all the businesses in Europe, about $85 \%$ - 90\% of new employments since 2015 and provided for two-thirds of the total private sector (European Commission, 2012).

Recently, the Vice President of Nigeria, Yemi Osinbajo stated that Micro, small and medium scale enterprises (MSMEs) made up about $90 \%$ and contribute half the GDP of businesses in the country. In 2019, the National Bureau of Statistics (NBS) and Small and Medium Enterprise Development Agency of Nigeria (SMEDAN) reported that SMEs is the prime mover for economic transformation. The reports between 2013 2017, indicated that in 2017 MSMEs in Nigeria generates 41.5 Million while, the small-scale enterprises accounted 71,000 businesses, making up to $0.17 \%$ and medium scale enterprises constituted $0.2 \%$ with 73,081 enterprises. Unlike the developed nations of the world, SMEs should generate employment, technological development and boost local value addition. The low figure and percentage contribution of SMEs show that the thinking of most tertiary institution graduates is about how they will get employment and not create one, which only a complementary entrepreneurship prowess can help them translate what is learnt into wealth. This could the learning orientation at institutions of higher learning did not give attention to the production of graduates with the mindsets of job creation (Henderman, 2013).

Unless Nigeria becomes mindful of the type of education that they want, tertiary institutions in Nigeria will certainly, continue to support the raising educated but unemployed persons (Development Policy Research Unit (DPRU) 2007; Adebisi \& Oni, 2012). According to the National Bureau of Statistics (NBS), the unemployment rate in Nigeria increased to 23.10\% in the third a quarter of 2018 from $22.70 \%$ in the second quarter of 2018. In 2019, Nigeria has about 25million graduates unemployment while, in early 2020, President Muhammadu Buhari estimated it at over 20million. NBS inability in updating the country's unemployment record as at when due, has not helped to make ready recent figures of the country's employment status. Nigeria has about 134 Polytechnics as of October 2019 and 174 Universities besides 144 colleges of education. The 308-degree awarding institutions alone allows for about 2 million students intake and produce about 800,000 graduates yearly.

As these institutions turn out graduates so do, the graduate employing factories continue to shrink. About 4.5 million graduates were reported to have stormed in internet space in less than two days when the Federal Government of Nigeria open the portal to her social intervention programme (N-Power) in June 2020 applying for the only 400,000 vacancies. The situation was not different when in 2014, 520,000 jobless graduates were said to apply for 4,000 advertised vacant positions in the Nigeria Immigration Service. An exercise that left many applicant loss their lives in the selection process. In 2018, the Mr Tunde Fowler was quoted as saying that a staggering number of 700,000 graduates applied for 500 advertised position in the Federal Inland Revenue Service (FIRS) employment. The situation did not change in 2019 where about 60,000 graduates sat for interviews in about less than 100 vacant positions at the Nigerian National Petroleum Corporation (NNPC). The National Bureau of Statistics reported that in the 2nd quarter of 2019, the national labour force was 69\%, and the employment-to-population ratio was $66.6 \%$, meaning $33.4 \%$ of the labour force were unemployed. From the foregoing, developing entrepreneurs behaviour will help project us towards global competitiveness. This we can attain if tertiary education can prepare students for the opportunity to gain entrepreneurship competence.

\section{RATIONALE FOR METALWORK TRADE DISCIPLINE}

One of the hallmarks of Metalwork Trade (MwT) of Vocational and Technological Education (TVET) is to equip the individual with skills and knowledge that will enable them to establish a business of their own and earn a living without looking for white-collar jobs (FRN, 2013). MwT is a term used to describe engineering discipline that has a relationship with metal welding, servicing and repairs of machines or machinerelated equipment and appliances for the design or production of objects (Yalams, 2001). The courses in this discipline include welding and fabrication, equipment mechanics work, machine operations, mechanical engineering craft practice, foundry craft practice, instrument mechanics and marine engineering craft (Ogundola, Popoola \& Oke, 2010). MwT training provides the learners with the practical skills in works aspects of mechanical engineering trades aimed at equipping students with the knowledge of production mechanics to work that will help them to be able to handle and use different tools, equipment, machinery and techniques of manufacturing.

These activities ultimately facilitate the shaping of materials into various usable forms to drive economic development. Importantly, MwT is one discipline that shares many common concepts and ideas with most fields of engineering and technology such as mechanical, chemical, electrical, and industrial engineering and its works are seen in almost every specialized disciplines which made it the most liberal compared to other fields of engineering (Dublin Institute of Technology, (2008). According to Yakubu (2014), MwT discipline offers the student the chance to,

1. Translate the knowledge gained in class to the real-life situation

2. Be able to manipulate tools/equipment and machines to produce items for human use.

3. Carry out qualitative metal product construction and grasp the steps to be taken during construction

4. Understand the properties of metal when selecting materials for production activities.

5. Be safety conscious and how best to apply precautionary measures at the workplace.

\section{METHODOLOGY}

This research adopted the narrative review approach supported with secondary data sourced from textbooks, journals and internet materials. A narrative review is the "traditional" way of reviewing the extant literature (Sylvester, Tate \& Johnstone, 2013) and does not seek generalization from what is been reviewed (Green, Johnson, Adams, 2006; Davies, 2000)

\section{CONCEPTUAL CLARIFICATIONS OF ENTREPRENEURSHIP, ENTREPRENEUR AND ENTREPRENEURSHIP EDUCATION.}

The Organization for Economic Cooperation and Development (OECD) entrepreneurship indicator programme (2009) described entrepreneurship as an enterprising human activity in pursuit of the generation of value through the creation or expansion of economic activity, by identifying and exploiting new products, processes or markets. According to (Ogundele, Sofoluwe \& Kayode, 2012; Suleman, 2010; Akanwa \& Agu (2005) it is the know-how of anyone setting up or running a new business entered through self-establishment or adopting an already existing business. (Ikotun, Oladimeji, Oyende \& Olayemi, 2014; Shane \& Vankataraman, 2000) viewed entrepreneurship to involve the discovery, creation and exploitation of opportunities to bring into existence future goods and services or creation of new enterprise. Entrepreneurship is viewed as an act and process conceiving new ideal involving a lot of time, efforts, skills and resources to bring to fusion. It follows that the ability to initiate and convert the ideals of entrepreneurship into economic realities is the act of being an entrepreneur (Wikipedia, 2014; Shane, 2003). 
An entrepreneur is derived from a French word known as 'entrepredre', translated to mean a person who voluntarily heads the military expedition. It has however been defined in many ways. (Osalor, 2013; Ojeife, 2012; Adako, 2005) described an entrepreneur as someone who has the ingenuity to create business opportunities through risks and initiative, attempts to make a profit or someone who facilitates adjustment to change spotting opportunities for profitable arbitrage (Kirzner, 1973). Knowledge acquisition and learning have been well emphasized as important factors to successful entrepreneurship over the last decades (Europeans Commission, 2013; Postigo, Iacobucci, \& Tamborini 2003; Sullivan 2000). Entrepreneurship education is a form of training that deals with the acquisition of skills, ideas and managerial competencies required for job creation and sustainability (Olorunmolu \& Agbede, 2012; Ghoshal, 2005). Teaching entrepreneurship in schools is aim to inspire and help students understand why some businesspersons can see and take up opportunities while others cannot.

Table 1. Some Common Metalwork Craft Technical Skills and Products

\begin{tabular}{|c|c|c|}
\hline Aspects of Metalwork & Technical Skills & Metalwork Products \\
\hline Welding and fabrication & $\begin{array}{l}{ }^{*} \text { Operate arc welding machine/ } \\
\text { equipment to correctly lay weld } \\
\text { beads on metal pieces. } \\
{ }^{*} \text { Prepare metal joints appropriately } \\
\text { for arc welding in horizontal, vertical } \\
\text { and angular positions } \\
{ }^{*} \text { Solder work pieces correctly using } \\
\text { electric soldering bit } \\
\text { *Weld metal pieces to form assembly } \\
\text { of parts correctly } \\
\text { *Fabricate/produce to correct } \\
\text { specifications simple sheet metal } \\
\text { projects/products in the metal shop }\end{array}$ & 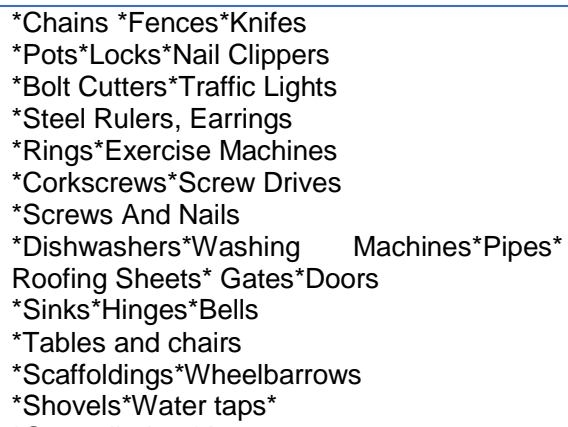 \\
\hline Machine operations & $\begin{array}{l}\text { *Operate lathe machine to accurately } \\
\text { *Prepare accurate work plan/ } \\
\text { operational sequence for turning jobs } \\
\text { on the lathe } \\
{ }^{*} \text { Operate milling machines to } \\
\text { correctly carry out basic milling } \\
\text { operations } \\
{ }^{*} \text { Operate shaping machine to shape } \\
\text { metal product/project } \\
\text { *Operate correctly and safely the } \\
\text { drilling machine to carryout basic } \\
\text { drilling operations } \\
{ }^{*} \text { Operate safely and correctly } \\
\text { computer numerical control (CNC) } \\
\text { machine to perform basic metal } \\
\text { machining operations. }\end{array}$ & $\begin{array}{l}\text { *Gas cylinders*Axes } \\
\text { *Water bottles*Window } \\
\text { Frames }{ }^{*} \text { Windows and doors burglaries }{ }^{*} \text { can } \\
\text { openers } \\
{ }^{*} \text { Cutlasses }{ }^{*} \text { Car jacks } \\
{ }^{*} \text { Tanks }{ }^{*} \text { Buckets among others. }\end{array}$ \\
\hline $\begin{array}{l}\text { Mechanical craft } \\
\text { Practice }\end{array}$ & $\begin{array}{l}\text { *Perform forge metal work pieces to } \\
\text { required shape using smith forge } \\
\text { *Produce simple engineering components by forging } \\
{ }^{*} \text { Prepare sand moulds correctly } \\
\text { *Operate foundry furnaces correctly to } \\
\text { melt metals for casting } \\
\text { *Produce simple metal components and } \\
\text { tools on the bench }\end{array}$ & \\
\hline
\end{tabular}

\section{OBJECTIVES OF ENTREPRENEURSHIP EDUCATION}

As a basis for evaluating the performance of the programme, Paul (2005) stated that entrepreneurship education is aimed at achieving the following objectives.

i. Provide education geared towards promoting self-employment of citizens.

ii. Gives training that will boost graduates creative and innovative capabilities to be able to identify business opportunities on their own.

iii. Promotion of economic growth of a nation

iv. Provides business risk management knowledge to graduates.

v. Reduction of poverty in individual, communities and country.

vi. Employment creation

vii. Migration reduction

viii. Gives enough training to graduates to enable them think about running small and medium-sized businesses.

ix. Promote transition to a modern industrial world.

\section{DEFINING LEARNING ENTREPRENEURSHIP MODEL IN HIGHER EDUCATION}

The instructional model is a systematic and reflective process of arrangement of resources and procedures for teaching (Dick, Carey \& Carey, 2005 ) as it provides guidelines for proposing a new teaching system (Shafique \& Mahmood, 2010b). Teaching technology-related trades require that teachers properly plan or follow a laydown guide to carryout instructional activities using available facilities to realize stipulated objectives. All perspectives towards the existing framework models of learning entrepreneurship is an input to the development of entrepreneurship education. Entrepreneurship education plays an important role in fostering soft skill in students and adjustment to change at all levels of the economic structure. There needs to put a teaching guide in place in which schools might provide specialized vocational entrepreneurship training in emerging technical skills needed for existing jobs and production practices and which encourages self/wage employment and improves its productivity. Learning entrepreneurship activities are still limited to theoretical practice, without emphasis on trade/entrepreneurship subjects (Ekene, 2015), 
and the prevalent instructional approach is the conventional classroom teaching as against the more efficient non-conventional methods (Chukwuma-Nwuba \& Yayock, 2013; Bell, 2015). Akpan, Effiong and Ele (2012) recommended that entrepreneurship education should be centred on practical orientation rather than the theoretical appreciation of the course in institutions.

\section{LEARNING ENTREPRENEURSHIP THROUGH SCHOOL-BASED ENTERPRISES MODEL}

School-Based Enterprises (SBE) are mainly organizational and economic framework that connects industrial technical to production for economic benefits. Products of SBE and the processes of manufacturing them are useful in training industrial education students to acquire more skills. Gugerty, Foley, Frank and \& Olson (2008) define school-based enterprise as a set of entrepreneurial activities undertaken by students that provides an economic, social and educational return to the student, school and community. According to Bath (2016), it is a hands-on learning environment and an entrepreneurial operation located in a school setting to identify, create, and sell goods or services that meet the needs of the specified market or target audience. It allows for learning to carry out production tasks for sale. These tasks contribute to learning in vocational education because it allows students to acquire more skills in the process.

School-Based Enterprises function like a mini business would offering a realistic work environment with real-world skills and work experience for students' later entering trade school, college or the workforce and fill a need in the marketplace for whatever type of goods or services the enterprise has chosen to market and sell. According to Bath (2016), SBE is advantageous to students in the following ways; provision of job interview experience, hands-on learning, work-based experience in all aspects of a business (inventory, marketing, accounting and more), tailored classroom education that integrates with the work experience, interpersonal skills such as stronger communication, self-confidence and problemsolving and pre-employment training that prepares students for the workforce. Ensuring that students benefit maximally has been the focus of SBE for a long time. The Maschinenfabrik Augsburg Nurnberg (MAN) Salzgitter model (a didactic model) developed in conjunction with the Germany Federal Institute for Vocational Training (GFIVT) in 1974 for imparting basic vocational competencies (Wiemann \& Günter, 1974). The model sought for a didactic alternative model for teaching vocational education by the transfer of competencies involving the principles of self-directed training. According to Madhu (2015), metalwork trades at MAN Salzgitter school-enterprise was conducted in basic industrial training through the use of integrated projects approach, specialized industrial training using project training didactic concept and industrial training in an enterprise by combining course and project-oriented instruction with on-the-job training an enterprise.

\section{INDUSTRIAL APPRENTICESHIP ENTREPRENEURSHIP-BASED LEARNING}

The Apprenticeship Training (AT) is adjudged the best way to supporting entrepreneurship training in Ghana and Kenya. Most technical skilled persons acquire their skills on-the-job outside the school system. Madhu (2015) pointed out that in the apprenticeship training system, a master craftsman takes on one or more trainees to be initiated into his craft, and they work with him under his instruction and guidance. In the past, apprenticeship has often been viewed as an aspect of industry rather than of education. As developing nations aspire a greater need for higher technical skilled manpower to drive economic development, there is need for entrepreneurship studies to adopt or incorporate an apprenticeship model that is not based upon the cheap workforce model of the developing countries informal sector, but instead one in which active learning is designed to develop a variety of process skills. Such on-the-job training is recognized as a part of the educational system when it is deliberate rather than accidental (Landgren, 1993). The Important dimensions of apprenticeships in entrepreneurship education are:

i. It a practice that allows trainers to acquire vocational skill under the supervision of practitioners.

ii. The duration of apprenticeships varies depending on the skills involved.

iii. In fully-fledged apprenticeships, attachment to an enterprise continues with the utilization of the increasing skills (manual and commercial skills) acquired over an extended period of learning

iv. Apprenticeship arrangements commonly involve the acquisition of skills that have wide applicability, hence are portable across agencies and activities.

v. Apprenticeships entail some sort of recognized obligation, formal or informal, on the part of the trainee. The alternative is a payment of fees by the trainee to master.

vi. The apprentice model of learning is an effective model of learning in schools for industrial enterprise. The student learns his basic competency skills in the context of a genuine work context. This contrasts with most existing vocational training programmes in which the rewards early on are limited, and in which students are older and have learned the basic competency skills out of context

\section{KINDS OF INDUSTRIAL ENTREPRENEUR SKILLS REQUIRED FOR SUCCESS}

Entrepreneurship education is a special type of education, which trains her recipients to acquire technical skills knowledge, innovative business ideas, industrial skills, creative ability, mental /psychological preparations and entrepreneurial abilities, which when apples can lead to enhanced self-reliance and boost economic development. Skill components vary in their degrees of general, specialized applicability and are acquired through technical, scientific or creative studies. Technical skills are skills acquired through specialized learning and adaptation. Generic skills are key competencies involving little or no interactions with machines, tools/equipment that helps students to obtain positive social relations and contributes to the work environment (Caleb \& Udofia, 2013; Kearns, 2001). Therefore, entrepreneurship studies should inculcate the following skills in the trainees' communication skills, entrepreneurial competencies, cognitive skills, social competencies, organizational competencies (managerial capabilities) and occupational problem solving (job performance). Occupational problem solving is possible by employing learning to integrate various techniques, social processes, various workplaces, various social relations, various management and administrative functions (job scheduling, job evaluation, insurance, health) and various production and entrepreneurial skills.

\section{CHALLENGES OF ENTREPRENEURSHIP EDUCATION IN NIGERIA}


The Federal Government of Nigeria (FGN) (2013) in her National Policy on Education framework noted that the goals of Technical and Vocational Education and Training (TVET) should be to;

i. To provide manpower in applied science, technology and business particularly at crafts, advance crafts and technical levels

ii. Provide the technical knowledge and vocational skills necessary for agriculture, commerce, economic development and

iii. Give and impart the necessary skills to an individual for self-reliance economically (which include setting up their businesses and be selfemployed and be able to employ others).

The goal (iii) above is mainly to develop entrepreneurship skills among undergraduates. This bestows a huge responsibility for institutions to contribute to achieving the goals of TVET. Unfortunately, many years after the adoption of entrepreneurship education in schools as a means to equip graduates with employability expertise, there have been persistent reports of graduates' unemployment due to the non-possession of employability skills (Oresanya, Omudewa, Kolade \& Fashedemi, 2014; Akinyemi \& Igot, 2012). However, several challenges currently face institutions in Nigerian as they attempt to teach entrepreneurship education. According to Amoor (2008), the challenges are as follows:

i. The less number of lecturers with practical knowledge of entrepreneurial training.

ii. The task of drawing up course content into the curriculum of entrepreneurship-related education programme in Nigerian universities is a time-consuming process (Blenker, Dreisler, Færgemann, \& Kjeldsen, 2008).

iii. Entrepreneurship education is capital intensive and both lecturers and students need money to practice the theory of initiating, establishing and running enterprises. This undoubtedly constitutes constraints, which subsequently frustrate the integration of the entrepreneurship in academic programmes in Nigerian universities.

On the other hand, Ojeifo (2013) highlighted seven problems hindering the development of entrepreneurship education in Nigeria. i) systemic corruption ii) low access to vocational skills development training iii) data for entrepreneurship education has been lacking. There is little or limited programme design for entrepreneurship education. iv) the presence of administrative and trade barrier that curtail capacity building and inhabit access to technical support. v) steady infrastructural deficit especially on the area of power supply and roads and systematic irregularities peculiar to small business. vi) absence of a pro-active regulatory environment that encourages innovative enterprise development at the grass-root level. vii) lack of capital to fund the teaching of entrepreneurship education in practical terms.

\section{CONCLUSION}

To be self-reliant means that an individual can garner and control economic resources above basic needs. Developing oneself to become independent takes time and as summarized in the words of Evans-Obinna (2016), it is through entrepreneurship education on can acquire the knowledge, skills, attitude and motivation to generate self-employment and wealth redistribution for economic independence. From the foregoing and in the realization of the goals of TVET, there is need for the industrial technology students to gain a form of training, which will help them recognize and converts opportunities of their technical knowledge into marketable ideals for wealth generation.

\section{RECOMMENDATIONS}

For entrepreneurship education in Nigerian to achieve its aim for TVET students, the following recommendations are projected.

i. The government should redesign the TVET curriculum to incorporate practical and industrial work base entrepreneurship skills.

ii. The government should establish a school-based enterprise in each institution offering TVET programme, where students can use their school as a mini incubator.

iii. The government should attach each student to a locally successful entrepreneur/firm with a clear established educational programme during the final year of their course work.

iv. The government should provide enough equipment/tools and facilities for the teaching of entrepreneurship skills in schools.

v. Teachers should shift emphasis from the traditional theory-based learning to a creative and innovative orientation approach.

\section{CONFLICT OF INTEREST}

There is no conflict in interest.

\section{References:}

Adako, L. B. (2005). Entrepreneurship in vocational education. Ado-Ekiti: Kaybis Global Links Ltd.

Adebisi, T. A. \& Oni, C. S. (2012). Assessment of relevance of National Directorate of Employment training programme to the needs of the trainees in South-West in Nigeria. International Journal of Vocational and Technical Education 4(3), 29 - 37.

Agbonifoh, B. A., Ehiametalor, E. T., Inegboenebor, A. U., Iyayi, F. (1999). The business enterprise in Nigeria: Nigeria: Longman Nigeria Plc.

Akanwa, B., \& Agu, C. N. (2005). Entrepreneurship: Theory and practice in Nigeria. Owerri, Nigeria: Resources Development Centre.

Akinyemi, S \& Igot, O. (2012). Planning and Funding of Higher Education in Nigeria: The Challenges. Journal of International Education Studies 5(4).

Akpan, E. I., Effiong, S. A \& Ele, A. A (2012). Entrepreneurship education: An intervention strategy for economic development in Nigeria. Business \& Entrepreneurship Journal 1(1), $101-10$

Amoor, S. S. (2008). Integrating entrepreneurship education into business education curriculum in Nigerian universities. Zaria Journal of Liberal Arts 2(2).

Araba, S. O. (2012). Entrepreneurship education as a tool for reducing unemployment in Nigeria, Retrieved online on April 12th, 2020 via www.academia.edu/2047944/entrepreneurial.

Azi, A. S. (2013). Economic implications of incessant crises in Jos: Entrepreneurship education as a panacea. The International Journal of Education Studies 1(3), $12-15$.

Bath, H (2016). School-Based Enterprise: Definition \& Goals. https://study.com/academy/lesson/school-based-enterprise-definition-goals.html

Bell, R. (2015), "Developing the next generation of entrepreneurs: Giving students the opportunity to gain experience and thrive", The International Journal of Management Education 13(1), 37 - 47. 
Blenker, P., Dreisler, P., Færgemann, H. M., \& Kjeldsen, J. (2008). A framework for developing entrepreneurship education in a University context. International Journal of Entrepreneurship and Small Business 5(1), $45-63$

Caleb, E. C \& Udofia, A. E (2013). Generic skills and the employability of electrical installation students in technical colleges of Akwa Ibom State, Nigeria. IOSR Journal of Research \& Method in Education 1(2), 59 - 67.

Chukwuma-Nwuba, E. O \& Yayock, J. Z. (2013). Entrepreneurship education (ee) in Nigerian colleges of education and engendering entrepreneurial intentions among the students. World Educators Forum, 2013.

Development Policy Research Unit (DPRU, 2006) Graduate unemployment in past-Apartheid South Africa: Nature and possible policy responses. Research report compiled for business leadership South Africa. Cape Town: School of Economics, University of Cape Town.

Ekene, N. I. (2015). Gaps in entrepreneurship education: Implications to science teaching in Nigeria. Entrepreneurship Education in Nigeria: Challenges and Prospects. Onitsha: Global Academic Press.

European commission (2013). Entrepreneurship education: A guide for educators. Retrieved online on June 19th, 2020 via C:/user/downloads/document/entredumanual-fv.en

Evans-Obinna, R. (2016). Entrepreneurship education for self-reliance and economic development in Nigeria. International Journal of Vocational and Technical Education Research 2(2), 9 - 14.

Gbemi, F. (2020). MSMEs: Oiling the wheels of Nigerian economy. Retrieved online on the 22th July, 2020 via https://businessday.ng/businesseconomy/article/msmes-oiling-the-wheels-of-nigerian-economy/

Ghoshal, S. (2005). Bad management theories are destroying good management practices. Academy of management Learning and Education (4), 75 - 91.

Green B. N., Johnson C. D., Adams A (2006). Writing narrative literature reviews for peer-reviewed journals: secrets of the trade. Journal of Chiropractic Medicine (3), $101-117$.

Gugerty, J. Foley, C. Frank, A., \& Olson, C. (2008). Developing and operating school based enterprises that empower special education students to learn and connect classroom, community, and career-related skills. The Journal for Vocational Special Needs Education (31), 19 - 56.

Henderman, G. (2013). The study of Entrepreneurship policy in higher education. Innovation (10), $221-229$.

Kearns, P (2001). Generic skills for the new economy: Review of research. Retrieved online on July 3rd, 2020 via https://www.ncver.edu.au/research-andstatistics/publications/all-publications/generic-skills-for-the-new-economy-review-of-research

Kirzner, L. M. (1973). Competition and entrepreneurship. Chicago: university of Chicago Press

Kumar, V. C. (2011). What is the role of an entrepreneur in economic development? Retrieved online on the April 17th 2020 via http://www.preservearticles.com/20110//43326/romle-of-on-entrepreneur-inecenomic-development

Kuratko, D. F \& Hodgetts, R. M (2001). Entrepreneurship: A contemporary approach. Texas: Harcourt College Publishers.

Landgren, C. R. (1993). Show me what I should know! Active contextual learning on the job - review essay. Economics of education review (Cambridge, MA) $12(2), 267-270$

Madhu, S. (2015). School Enterprises: Combining Vocational Learning with Production. file:///C:/Users/HP/Downloads/School-based\%20enterprise\%201.pdf

Mbiewa, O. L (2011). Entrepreneurship education in Nigerian education institution. Journal of Technology and Education in Nigeria 16(2).

Ogundele, M. O., Sofoluwe, A. O., \& Kayode, D. J. (2012). Integrating entrepreneurship skills acquisition in to the National Youths Service Corps (NYSC) Programme in Nigeria. Journal of Entrepreneurship and Management 1(3), 24 - 28.

Ojeifo, S. A. (2012). Entrepreneurship education in Nigeria. Journal of Education and Practice 3(14), $78-82$.

Ojeifo, S. A. (2013). Entrepreneurship education in Nigeria: A Panacea for unemployment. Journal of Education and Practice 4(6), 61 - 67

Olajide, O. (2019). Promoting entrepreneurship education in Nigeria for job growth. Retrieved online 23 July, 2020 via http://www.financialnigeria.com/promotingentrepreneurship-education-in-nigeria-for-job-growth-blog-442.html

Olorunmolu, J. O \& Agbede, E. A (2012). Quality entrepreneurship education: A panacea for job creation in Nigeria. Journal of Resourcefulness and Distribution (JORESDIS) 1(1).

Omolayo B. (2006). Entrepreneurship in theory and practice. In Onsotosho, A., Awe, W. \& Aderamola (Eds). Introduction to entrepreneurship development in Nigeria. Ado-Ekiti: UMAD Press.

Oresanya, T. O., Omudewa, O. S., Kolade, T. T \& Fashedemi, A. O. (2014). Vocational Education and Employability: The Nigerian Situation. Journal of Poverty, Investment and Development- An Open Access International Journal (3), 158 - 160.

Osagagi, S. M (2006). Entrepreneurship development policy: A renewed perspective for achieving economic development in Nigeria. Nigerian Academy of Management Journal (1), 109 - 122.

Osalor, P. (2013). Entrepreneurship education revolution: An imperative for sustainable development in Nigeria (1). Vanguard Newspaper (Lagos), 04 November.

Osuagwu, L. (2001). Small business and entrepreneurship management. Lagos: Grey Resources Limited.

Paul, E. O (2005). Entrepreneurship education: Ozybel Publishers, Enugu.

Postigo, S., D. Iacobucci, and M. F. Tamborini. 2003. Undergraduate students as a source of potential entrepreneurs: A comparative study between Italy and Argentina. Paper presented at the 2003 IntEnt conference, Grenoble.

Shane, S. \& Vankataraman, S. (2000). The promise of entrepreneurship as a field of research. Academy of Management Review $25(1), 217$ - 226.

Shane, S. 92003). The genetics of entrepreneurship performance. International Small Business Journal 31(5), 473 - 495.

Sullivan, R. 2000. Entrepreneurial learning and mentoring. International Journal of Entrepreneurship Behaviour and Research 6 (3), 160 - 175.

Tende, S. B (2014). Government initiatives toward entrepreneurship development in Nigeria. Global Journal of Business Research 8 (1), 109 - 120.

Wiemann, Günter et al. (1974). Didaktische Vorstudie für ein projektorientiertes Handlungsmodell beruflicher Grundbildung (im Berufsfeld Metall), Bundesinstitut für Berufsbildungsforschung, Berlin

Wikipedia, (2014). Entrepreneurship education. Retrieved online on June 16th, 2020 via http://en.wikipedia.org/wiki/entrepreneurship_education

Yakubu, B (2014). The need for competency in metalwork technology in Nigerian technical colleges. Journal of Emerging Trends in Educational Research and Policy Studies (JETERAPS) 5(8), $153-154$. 